\title{
Socioeconomic and Environmental Determinants of Health Outcomes: The Case of Transition Economies
}

\section{Społeczno-ekonomiczne i środowiskowe determinanty zdrowia: przypadek gospodarek $\mathrm{w}$ okresie przejściowym}

\author{
Ebru Çağlayan-Akay ${ }^{*}$ Zamira Oskonbaeva** \\ *Department of Econometrics, Marmara University, Istanbul, Turkey \\ ORCID: 0000-0002-9998-5334 \\ **Department of Economics, Kyrgyz-Turkish Manas University, Bishkek, Kyrgyzstan \\ E-mail: zamira.oskonbaeva@manas.edu.kg, ORCID: 0000-0002-3711-6918
}

\begin{abstract}
This study examines the effects of economic and socio-demographic factors on the health status of men and women separately. The annual data of 16 selected transition countries for the period 2000-2016 were used. Life expectancy at birth was used as an indicator of health status in the study. Economic and environmental variables such as GDP per capita, health expenditures, unemployment, carbon emissions, access to safe water, and urbanization are considered as factors affecting life expectancy at birth. In the study, the Autoregressive Distributed Lags (ARDL) model was used.

The findings show that the effects of socioeconomic and environmental factors on life expectancy differ according to men and women. It has been found that above-mentioned factors are more effective on life expectancy of men than women in selected transition economies. Therefore, it can be recommended to prioritize economic and environmental targets in improving the health outcomes of countries.
\end{abstract}

Key words: Panel ARDL model, transition economies, health, socioeconomic factor, life expectancy

\section{Streszczenie}

W artykule przeanalizowano wpływ czynników ekonomicznych i społeczno-demograficznych na stan zdrowia kobiet i mężczyzn. Wykorzystano dane z 16 wybranych krajów reprezentujących gospodarki w okresie przejściowym za lata 2000-2016. W badaniu jako wskaźnik stanu zdrowia wykorzystano oczekiwaną długość życia w chwili urodzenia. Za czynniki wpływające na oczekiwaną długość życia w chwili urodzenia są uważane zmienne gospodarcze i środowiskowe, takie jak PKB na mieszkańca, wydatki na zdrowie, bezrobocie, emisje dwutlenku węgla, dostęp do czystej wody i urbanizacja. W badaniu wykorzystano model Autoregressive Distributed Lags (ARDL).

Okazuje się, że wpływ czynników społeczno-ekonomicznych i środowiskowych na oczekiwaną długość życia różni się w zależności od płci. Stwierdzono, że wyżej wymienione czynniki wpływają bardziej na długość życia mężczyzn niż kobiet w wybranych gospodarkach w okresie przejściowym. Dlatego należy zalecić priorytetowe potraktowanie celów ekonomicznych i środowiskowych w poprawie wyników zdrowotnych krajów.

Slowa kluczowe: Model panelowy ARDL, gospodarki w okresie przejściowym, zdrowie, czynnik społecznoekonomiczny, długość życia

\section{Introduction}

Nowadays, healthcare emerges as a very important input for economic growth, poverty reduction and long-term economic development (Asafu-Adjaye,
2007; Smith, 1999). At the macro level, protecting and improving population health is accepted as one of the basic policies of sustainable development (Bayati et al., 2013). In addition, health is considered to be essential input to sustainable development. 
Without healthy nation it is hard to build prosperous society. Its value as a vital stimulus for development has contributed to the central positioning of healthrelated targets in the Sustainable Development Goals. Sustainable Development Goals (SDGs), a series of priorities adopted by member states of the United Nations as essential to sustainable human progress. Only SDG 3 is devoted to health. Nevertheless, health plays a major role in achieving other goals, too (Mohammed and Ghebreyesus, 2018). In other words, other development objectives such as poverty alleviation, gender empowerment, and universal education can be achieved through improved health status of population. It is stressed that overall economic and social progress cannot be sustainable without increasing health outcomes (Health in the Framework of Sustainable Development, 2014). So health has become a more pertinent issue in development, both as a contributor to and as a measure of sustainable development. For this reason, exploring the core factors that determine health status of people is vital to ensuring sustainable development.

Life expectancy at birth is often used to measure the health status of a population as well as to assess the improvement in health status in each country. Although health is a multidimensional concept, life expectancy at birth is one of the most widely used population health indicators (Sharma, 2018). Bilas et al. (2014) suggested that life expectancy is an important indicator in evaluating the economic and social development of a country or region. According to Pasichnyi and Nepytaliuk (2021) longevity can be considered as the direct consequence of the high economic development.

According to the World Health Report of the World Health Organization, people live healthier and longer today than they did 30 years ago. From 1998 to 2025 , it is estimated that the average global life expectancy will increase by 7 years and life expectancy in 26 countries will exceed 80 (World Health Organization, WHO, 2008). Life expectancy increased by $8 \%$ globally between 2000-2016 (World Health Statistics, 2020).

It is argued that life expectancy depends more on lifestyle (Luy and Wegner-Siegmundt, 2015; Oksuzyan et al.2008), environmental (Mariani et al.2009; Elo and Preston, 1992; Evans and Smith, 2005), economic (foreign direct investment and external trade (Herzer and Nunnenkamp, 2012; Owen and $\mathrm{Wu}, 2007$ ), economic growth (Salahuddin, 2020) and socio-demographic (urbanization (Rogers and Wofford, 1989), access to safe water (Rogers and Wofford, 1989; Gullis, 2000) ), education (Luy et al.2019; Lleras-Muney, 2005), and income inequality (Matthew and Brodersen, 2018) factors.

It is extremely important to examine health outcomes for transition economies. Because these countries have been exposed to political, social and economic changes in the 1990s. Political and social transformations have also had significant effects on population health (Nolte et al. 2005; Grigoriev et al. 2010). Factors experienced during the transition period such as the increase in unemployment, the de- crease in living standards, imbalances in income distribution and psychological stress caused health outcomes to deteriorate (Cornia and Paniccia, 2000; Cockerham et al. 2006). It has been observed that the differences in life expectancy by gender are also beginning to increase. While men living in the Commonwealth of Independent States (CIS) countries in the 1960s lived 12 years longer than the global average, towards 2012 it is seen that their life expectancy was two years less than the world average. It has also been observed that there is a decrease for women life expectancy. While women lived 14 years longer than women in other countries in the early 1960s, towards 2012 this difference was recorded as two years.

It has been well documented that the socioeconomic factors may lead to better improved health outcomes of population (Sede and Ohemeng, 2015; Miladinov, 2020; Salami et al. 2019). Improvements in economic conditions are an important force behind the population health outcomes (Miladinov, 2020). In other words, the impact of economic conditions on health status could not be neglected (Hsiao, 2004). The results of prior research have highlighted that countries should take into account not only health care and healthful behaviors, but also the social and economic conditions that so strongly impact the health outcomes. Moreover, it has been stressed that other health factors such as health behaviors, clinical care, and the physical environment are impacted by socioeconomic factors. A large portion of health outcomes (40 percent) is attributable to socioeconomic factors. The two factors socio-economic and environmental factors are found to be more important than other factors (Swain, 2016).

It is assumed that advances in health are the by-product of higher income as nations with higher income dedicate more money for their health care, which will result in better health outcomes (Stengos et al., 2008). Moreover, higher incomes promote access to goods and services (e.g. food, accommodation, transport), decent working standards and a better quality of life, which in turn leads to increased health and longevity. Prior researches highlighted that income is one of the main drivers of increasing life expectancy.

The impact of unemployment on longevity has been an important issue for researchers (Ahn et al., 2004). Unemployment has an adverse impact on health since, rising unemployment increase stress and depressed mood (Dooley et al. 1988; Mckee-Ryan et al. 2005), spread unhealthy behaviours (Bolton and Rodriguez, 2009), and elevate mortality risk (Noelke and Beckfield, 2014).

There is a related literature on the impact of health expenditure on health outcomes. It is assumed that rising health expenditure can lead to improvements in health. The empirical literature shows that total health care expenditure per capita leads to an increase in life expectancy (Chireshe and Ocran, 2020; Karaman et al. 2020). In other words, health expenditures were found to be essential for improving population's health. Health expenditure was found to be a significant explanatory variable for at least one 
Figure 1. Life expectancy of women vs. life expectancy of men, 2020, source: UN population division (2019 Revision), World Bank WDI

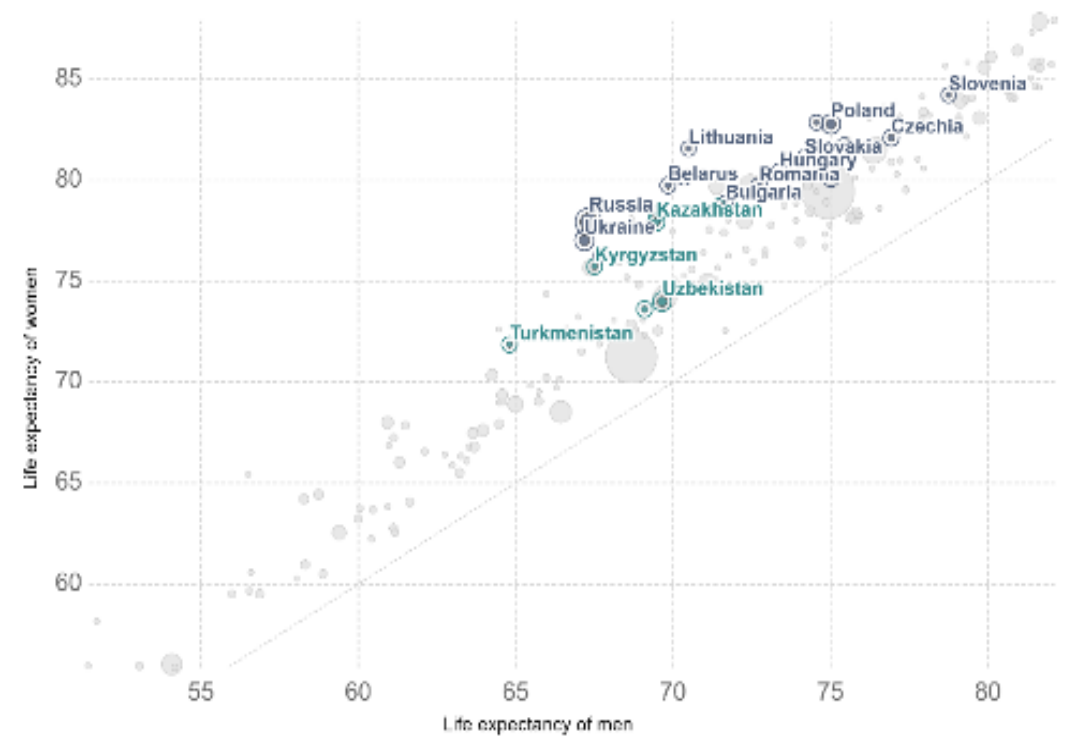

Figure 2. Life expectancy vs. health expenditure per capita, 2015, source: UN population division (2019 Revision), World Bank WDI

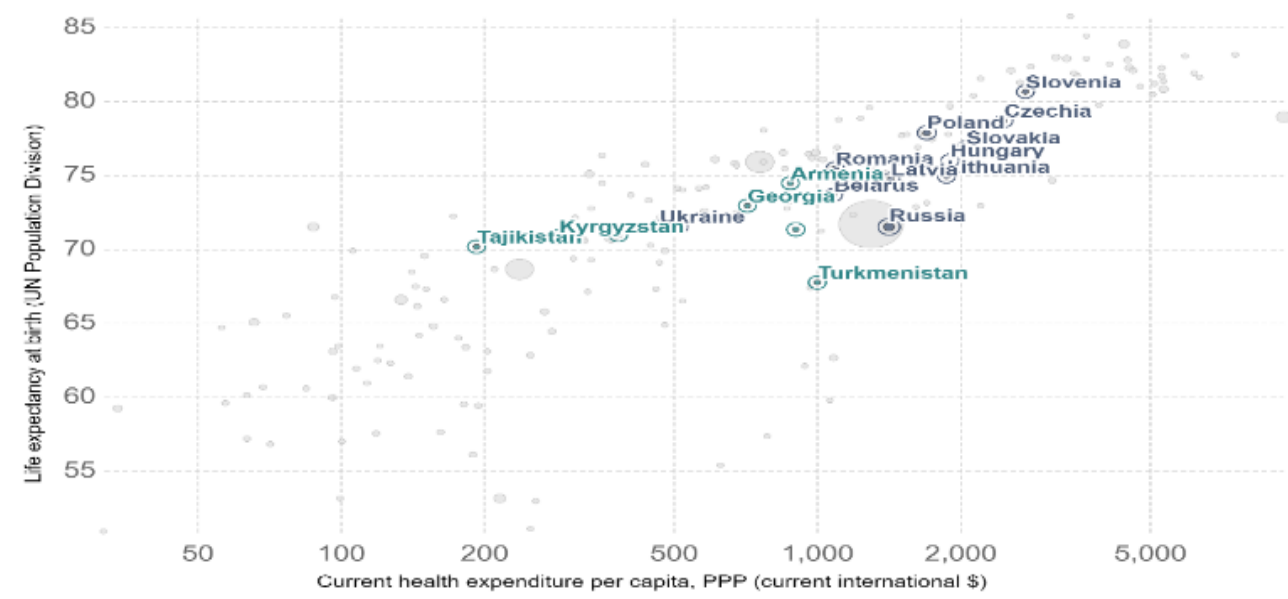

health outcome examined in 12 of 16 papers (Nixon and Ulmann, 2006). The contribution of health expenditure on health status may be differ according to gender. The evidence highlight that health care expenditure added 2.6 years to males and 2.8 years to female life expectancy.

The variation of life expectancy also can be explained by environmental factors. Much attention has been devoted to the contribution of urbanization, carbon emissions and access to safely water to health status.

Understanding the underlying factors of longevity is vital in devising effective health policies. The importance of aforementioned socioeconomic and environmental factors in enhancing health motivated us to conduct this study. So the scope of this study is to link the key parameters of socio-economic and environmental factors with longevity prospects. This study examines economic and environmental factors affecting life expectancy of women and men in selected transition economies (Armenia, Belarus, Bulgaria, Georgia, Estonia, Hungary, Kazakhstan, the
Kyrgyz Republic, Latvia, Lithuania, Moldova, Russian Federation, Slovak, Slovenia, Tajikistan, and Uzbekistan). In the empirical analysis, the annual data of these countries for the period 2000-2016 were used. Panel ARDL model was employed to reveal the effects of economic and environmental factors such as GDP per capita, health expenditures, unemployment, access to safe water, urbanization, and carbon emissions. Findings obtained from the study indicated that the effects of economic and environmental factors on life expectancy differ by gender. The contribution of this study to the literature can be considered from the two aspects. First, it is examined whether health outcomes differ by gender in transition economies. When the literature is examined, no other study has been found that deals with transition economies and examines them from this perspective. It is seen that there is no study focusing on the relationship between socioeconomic, environmental variables and the life expectancy of women and men. Secondly, there is no other study using the panel ARDL model applied in this study in the context of 
Figure 3. Life expectancy vs. GDP per capita, 2015, source: UN population Division (2019), Maddison Project Database (2018), Population Gapminder Hyde (2016) \& UN (2019), https://ourworldindata.org/

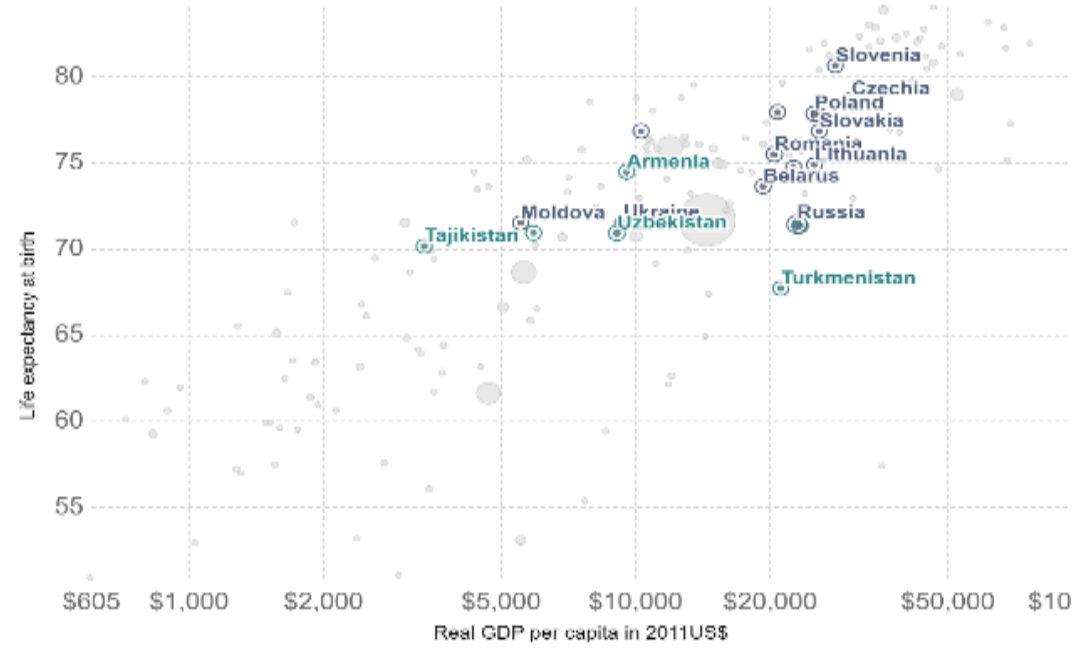

Figure 4. Life expectancy vs. $\mathrm{CO}_{2}$ emissions per capita, 2014, source: UN population Division (2019), Maddison Project Database (2018), Population (Gapminder Hyde (2016) \& UN (2019), https://ourworldindata.org/

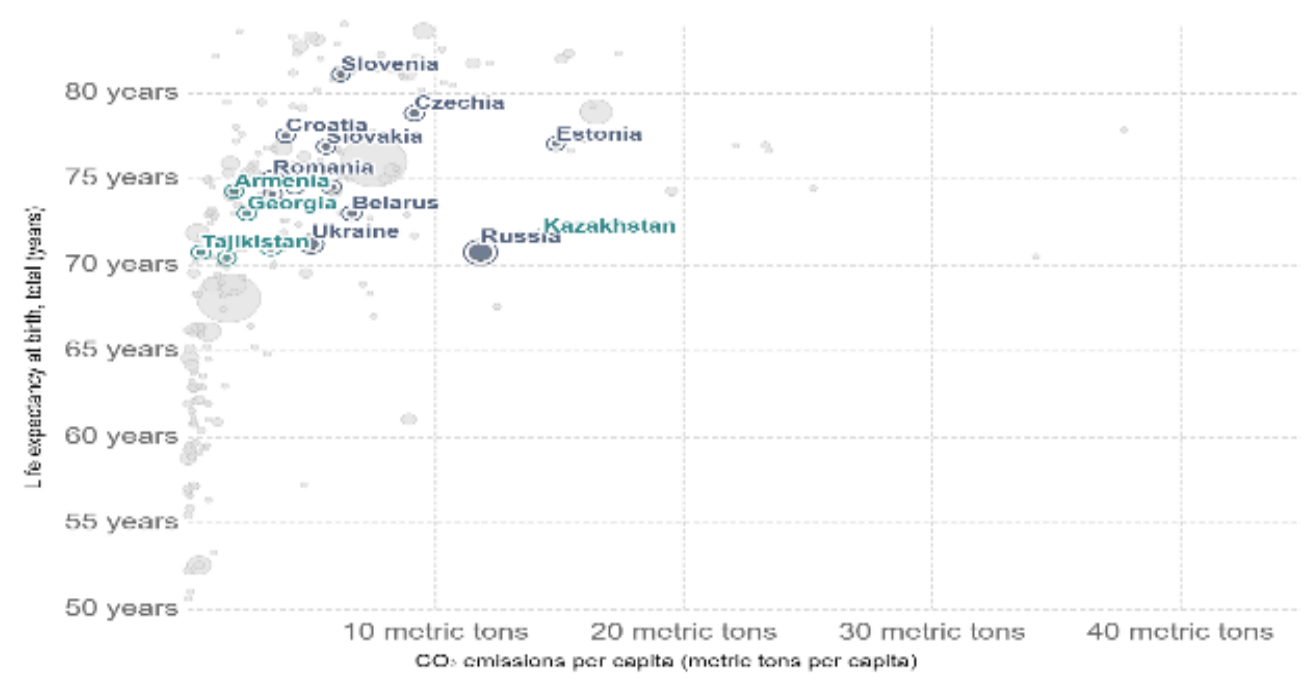

transition economies. This model is used in order to examine both potential long and short-term effects between the variables.

In the second section following the introduction, contributing factors to life expectancy in transition economies are elaborated. In the third section, studies examining the main determinants of health are emphasized. The data set and variables are introduced in the fourth section. The methodology and findings are given in the fifth section. Our study ends with the conclusion part.

\section{Contributing factors to life expectancy in tran- sition economies}

The life expectancy can differ by gender. Gender discrepancies in life expectancy are a global phenomenon. It is widely known that women live longer than men (Pinkhasov et al. 2010). According to the researchers, the reasons for this are based on biological, psychological and social factors. The difference in life expectancy according to gender has been the focus of attention of researchers (Sundberg, 2018). It is suggested that $75 \%$ of this difference is due to nonbiological (behavior, lifestyle, social roles etc.) factors (Luy and Wegner-Siegmundt, 2015; Oksuzyan et al. 2008). Since men consume more tobacco, use alcohol and are employed in more risky professions than women (Loef and Walach 2012; Oksuzyan et al. 2008) they live shorter lives.

As can be observed from Figure 1 in selected transition economies life expectancy of women is higher than for men. All countries lie above the grey line.

Figure 2 shows that there is positive correlation between life expectancy and health expenditure in selected transition economies. It implies that people in selected transition economies will live longer with increasing level of health expenditure.

In Figure 3 is shown the relationship between life expectancy and income. It indicates that there exists a strong, positive relationship between two variables. 
The increase in lifespan can be achieved by increasing in income.

In Figure 4 is plotted the relationship between the environment and health outcomes in transition economies. It can be observed from the Figure 4 that the life expectancy is higher in countries with low carbon emission, suggesting that environmental degradation is not good for longevity. Based on the above-mentioned drivers of health outcomes, empirical analysis were conducted by utilizing socioeconomic and environmental factors in the fifth section of this study.

\section{Literature review}

After the seminal paper of Auster et al. (1969), revealing the main determinants of health has become the focus of attention of researchers. The number of studies examining factors affecting health employing different methods for different countries has started to increase. It is observed that most of the previous studies dealt with the variables of economic, socio-demographic, environmental, lifestyle, access to health services as the main determinants of health. Life expectancy and infant mortality rates are frequently used as an important indicator of health. Another striking issue is that researchers mostly focused on OECD, European countries and the USA. Some of these studies are summarized in Table 1.

As can be seen from literature, researchers mostly focused on the effects of lifestyle (Shaw et al. (2005), environmental (Auster et al., 1969), economic (Salahuddin et al. 2020; BlazquezFernández et al., 2017) and socio-demographic (Rogers and Wofford, 1989; Gulis, 2000; Luy et al., 2019; Fayissa and Gutema, 2005) factors on health outcomes.

Kobza and Geremek (2015) linking health outcomes for Poland with lifestyle and health system, Korbelius et al. (2016) examined the effects of socioeconomic, health expenditures and environmental factors on life expectancy for the Czech Republic, Drastichová and Filzmoser (2020) investigated the impact of health expenditure on health outcomes, and Medas (2015) explored the impact of socioeconomic factors for Hungary.

When the previous literature is examined, it has been observed that transition economies are not considered altogether and are not investigated in the context of socioeconomic and environmental factors. Therefore, this study has two main differences from other studies. Firstly, this study focuses on the impact of socioeconomic and environmental factors on the health outcomes of women and men in transition economies. Secondly, the procedure employed in our study was not applied in previous studies.

\section{Data set and variables}

In this study, the annual data of 16 selected transition economies (Armenia, Belarus, Bulgaria, Georgia, Estonia, Hungary, Kazakhstan, Kyrgyz Republic,
Latvia, Lithuania, Moldova, Russian Federation, Slovak, Slovenia, Tajikistan, and Uzbekistan) for the period 2000-2016 were employed.

These countries were selected for three reasons: first, due to data attainability the number of countries are limited to these countries. Second, as can be seen from the prior literature panel data approach has not been applied in the context of transition economies, yet. Third, this study examines gender differences in life expectancy. It is known that economic and structural transformation that have taken place in 1990s affected the health status of people. It is well documented that political and economic transition in Eastern Europe and the former Soviet Union has been followed by a five-year drop in male life expectancy (Von Schirnding and Mulholland, 2002). On the basis of the reasons mentioned above current study will investigate the key determinants of health outcomes in the context of transition economies.

Life expectancy at birth was used as an indicator of health in the study. It has been emphasized in previous studies that the factors affecting the life expectancy of women and men differ according to gender. In this study socioeconomic and environmental factors are used as explanatory variables. Socioeconomic influences on life expectancy are represented by three variables: income per capita (Salami et al. 2019), unemployment (Norström et al. 2017) and health expenditure (Sede and Ohemeng, 2015).

Prior researches revealed that income is one the main determinants of health status. The existence of a significant positive association between income and health has been emphasized in the literature (Case et al. 2002; Deaton, 2002). It is believed that positive impact of per capita income on health can be observed untill some threshold level, beyond which it is expected that adverse risky behaviors and unhealthy lifestyle to be prevail that may be detrimental to health (Chris James and Franco, 2017; De Vogli et al., 2005). Based on past studies squared term of income was included into the model.

While some of the studies examining the effect of health expenditures by gender emphasized that it has a stronger effect on female life expectancy (Ivaschenko, 2005), in others it has been revealed that it is more effective on men (Crémieux et al. 1999). So the results are mixed.

Unemployment can worsen health status (Marmot and Wilkinson, 2003) firstly, increasing unemployment means decreasing income, secondly, unemployment increases chronic disease (cardiovascular disease, hypertension, and musculoskeletal disorders) and premature mortality (Dean and Wilson, 2009). Health effect of unemployment may differ according to gender. As can be observed from D'Arcy's (1986) study women are tend to be more anxious, depressive and visited doctors more often than unemployed men. Dew et al. (1992) argued that negative impact of unemployment on health status of women is higher than on the men. The results of other study indicate that men with longer unemployment duration died earlier (Lavis, 1998). 
Table 1. Literature review

\begin{tabular}{|c|c|c|c|}
\hline Author & Country & Method & Findings \\
\hline $\begin{array}{l}\text { Salahuddin et al. } \\
\text { (2020) }\end{array}$ & $\begin{array}{l}\text { South Africa } \\
1985-2016\end{array}$ & ARDL model & $\begin{array}{l}\text { It has been observed that economic growth } \\
\text { and foreign direct investments have a } \\
\text { negative effect on child mortality. }\end{array}$ \\
\hline $\begin{array}{l}\text { Miladinov } \\
(2020)\end{array}$ & $\begin{array}{l}\text { Macedonia, Serbia, } \\
\text { Bosnia and } \\
\text { Herzegovina, } \\
\text { Montenegro, and } \\
\text { Albania 1990-2017 }\end{array}$ & $\begin{array}{l}\text { Full Information } \\
\text { Maximum Likelihood } \\
\text { method }\end{array}$ & $\begin{array}{l}\text { It has been demonstrated that an increase } \\
\text { in GDP per capita and a decrease in infant } \\
\text { mortality rates will improve life } \\
\text { expectancy at birth. }\end{array}$ \\
\hline $\begin{array}{l}\text { Luy et al. } \\
\text { (2019) }\end{array}$ & $\begin{array}{l}\text { Italy, Denmark, and } \\
\text { USA 1990-2010 }\end{array}$ & $\begin{array}{l}\text { A decomposition } \\
\text { Analysis }\end{array}$ & $\begin{array}{l}\text { Education has been found to improve } \\
\text { health. }\end{array}$ \\
\hline $\begin{array}{l}\text { Matthew and } \\
\text { Brodersen (2018) }\end{array}$ & $\begin{array}{l}\text { USA } \\
2006-2014\end{array}$ & $\begin{array}{l}\text { Probit regression } \\
\text { analysis }\end{array}$ & $\begin{array}{l}\text { It was concluded that income inequality } \\
\text { has an impact on health. }\end{array}$ \\
\hline $\begin{array}{l}\text { Rahman et al. } \\
\text { (2018) }\end{array}$ & $\begin{array}{l}\text { SAARC-ASEAN } \\
\text { countries } \\
\text { 1995-2014 }\end{array}$ & Panel data regression & $\begin{array}{l}\text { It has been demonstrated that total, public } \\
\text { and private health expenditures } \\
\text { significantly reduce infant mortality rates. } \\
\text { Increase in per capita income and } \\
\text { improved sanitation facilities contributed } \\
\text { to the improvement of population health in } \\
\text { the region. }\end{array}$ \\
\hline $\begin{array}{l}\text { Blazquez-Fernández } \\
\text { et al. (2017) }\end{array}$ & $\begin{array}{l}\text { OECD Asia / Pacific } \\
\text { region countries1995- } \\
2013\end{array}$ & $\begin{array}{l}\text { Panel and time series } \\
\text { analysis }\end{array}$ & $\begin{array}{l}\text { Empirical results show that per capita } \\
\text { income, unemployment and exchange } \\
\text { rates lead to different health outcomes. It } \\
\text { has also been found that spending more on } \\
\text { healthcare expenditures does not always } \\
\text { yield better results. }\end{array}$ \\
\hline $\begin{array}{l}\text { Tavares } \\
(2017)\end{array}$ & $28 \mathrm{EU}$ countries & Panel data regression & $\begin{array}{l}\text { GDP and giving birth before the age of } 20 \\
\text { have been shown to affect infant mortality. } \\
\text { It has been observed that infant mortality } \\
\text { rate decreases as the mean age of the } \\
\text { mothers for the first child increases. }\end{array}$ \\
\hline $\begin{array}{l}\text { Asiskovitch } \\
(2010)\end{array}$ & $\begin{array}{l}19 \text { OECD countries } \\
1990-2005\end{array}$ & Panel data regression & $\begin{array}{l}\text { The health system has found a marginal } \\
\text { effect on life expectancy at birth for both } \\
\text { sexes. Public finance has a greater impact } \\
\text { than private. }\end{array}$ \\
\hline $\begin{array}{l}\text { Fabella } \\
(2008)\end{array}$ & $\begin{array}{l}134 \text { countries } \\
2000 \text { and } 2003\end{array}$ & $\begin{array}{l}\text { Cross-section data } \\
\text { analysis }\end{array}$ & $\begin{array}{l}\text { It has been demonstrated that the increase } \\
\text { in the population increases the infant } \\
\text { mortality rate. }\end{array}$ \\
\hline $\begin{array}{l}\text { Soares } \\
(2007)\end{array}$ & $\begin{array}{l}\text { Brazil states } \\
1970-2000\end{array}$ & Panel data regression & $\begin{array}{l}\text { Availability of healthcare infrastructure } \\
\text { has a significant impact on life } \\
\text { expectancy. }\end{array}$ \\
\hline $\begin{array}{l}\text { Nixon and Ullman } \\
(2006)\end{array}$ & $\begin{array}{l}15 \text { EU countries } \\
1980-1995\end{array}$ & Panel data regression & $\begin{array}{l}\text { Health expenditures have been found to } \\
\text { have a marginal but positive effect on } \\
\text { health outcomes for EU countries. It has } \\
\text { been revealed that the change in health } \\
\text { expenditures and the number of physicians } \\
\text { in EU countries adds } 2.6 \text { and } 1.6 \text { years to } \\
\text { male life expectancy, respectively, and } \\
\text { causes a } 0.63 \text { and } 0.22 \text { percentage point } \\
\text { decrease in infant mortality rate. }\end{array}$ \\
\hline $\begin{array}{l}\text { Afonso and St. Aubyn } \\
\text { (2006) }\end{array}$ & $\begin{array}{l}30 \text { OECD countries } \\
2000 \mathrm{y} 1 l_{1}\end{array}$ & $\begin{array}{l}\text { Two-step procedure for } \\
\text { cross section data: data } \\
\text { envelopment analysis } \\
\text { and Tobit regressions }\end{array}$ & $\begin{array}{l}\text { GDP per capita, education, tobacco use } \\
\text { and obesity were found to be factors } \\
\text { affecting health status }\end{array}$ \\
\hline $\begin{array}{l}\text { Fayissa and Gutema } \\
\text { (2005) }\end{array}$ & $\begin{array}{l}31 \text { Sub-Saharan African } \\
\text { countries } \\
1990-2000\end{array}$ & $\begin{array}{l}2 \text { stages } \\
\text { Generalized Least } \\
\text { Squares (GLS) method }\end{array}$ & $\begin{array}{l}\text { It is concluded that the increase in per } \\
\text { capita income and in the food availability } \\
\text { variable and the decrease in the rate of } \\
\text { illiteracy will improve life expectancy at } \\
\text { birth. }\end{array}$ \\
\hline $\begin{array}{l}\text { Shaw et al. } \\
(2005)\end{array}$ & $\begin{array}{l}19 \text { OECD countries } \\
1990\end{array}$ & Cross section analysis & $\begin{array}{l}\text { It has been observed that doubling annual } \\
\text { drug spending will result in an increase in } \\
\text { life expectancy for } 40 \text {-year-old men from } \\
1 \text { year to less than a year for } 65 \text {-year-old } \\
\text { women. It was concluded that reducing }\end{array}$ \\
\hline
\end{tabular}




\begin{tabular}{|c|c|c|c|}
\hline & & & $\begin{array}{l}\text { tobacco use to two per day or increasing } \\
\text { fruit and vegetable consumption by } 30 \% \\
\text { would result in an approximately one-year } \\
\text { extension in life expectancy for } 40 \text {-year- } \\
\text { old women. }\end{array}$ \\
\hline $\begin{array}{l}\text { Thornton } \\
\text { (2002) }\end{array}$ & $\begin{array}{l}\text { USA states } \\
1990\end{array}$ & $\begin{array}{l}\text { Cross-section data } \\
\text { regressions }\end{array}$ & $\begin{array}{l}\text { The contribution of medical care in } \\
\text { lowering the mortality rate is very low. } \\
\text { More attention should be paid to the role } \\
\text { of socioeconomic and lifestyle factors in } \\
\text { preventing disease and improving life } \\
\text { expectancy. }\end{array}$ \\
\hline $\begin{array}{l}\text { Lichtenberg } \\
(2002)\end{array}$ & $\begin{array}{l}\text { ABD } \\
1960-1997\end{array}$ & $\begin{array}{l}\text { Maximum likelihood } \\
\text { method }\end{array}$ & $\begin{array}{l}\text { Medical innovation and medical care } \\
\text { expenditures (especially public } \\
\text { expenditures) have had positive effects on } \\
\text { life expectancy. }\end{array}$ \\
\hline $\begin{array}{l}\text { Or } \\
(2000 a)\end{array}$ & $\begin{array}{l}21 \text { OECD countries } \\
1970-1992\end{array}$ & Panel data regression & $\begin{array}{l}\text { It is concluded that the increase in the } \\
\text { employment share of white-collar workers } \\
\text { and the per capita income is effective in } \\
\text { decreasing of premature deaths. An } \\
\text { important and positive relationship was } \\
\text { found between health expenditures and } \\
\text { health status, especially for women. }\end{array}$ \\
\hline $\begin{array}{l}\text { Or } \\
(2000 b)\end{array}$ & $\begin{array}{l}21 \text { OECD countries } \\
1970-1995\end{array}$ & Panel data regression & $\begin{array}{l}\text { It has been demonstrated that the increase } \\
\text { in the number of physicians per person } \\
\text { will lead to a decrease in early death rates, } \\
\text { perinatal and infant mortality rates, and a } \\
\text { longer life expectancy and lower heart } \\
\text { diseases, especially at the age of } 65 \text {. }\end{array}$ \\
\hline $\begin{array}{l}\text { Gulis } \\
(2000)\end{array}$ & $\begin{array}{l}156 \text { countries } \\
1990\end{array}$ & $\begin{array}{l}\text { Multivariable linear } \\
\text { model }\end{array}$ & $\begin{array}{l}\text { The strong effect of education and access } \\
\text { to safe water on health was emphasized. It } \\
\text { has been demonstrated that a } 10 \% \text { increase } \\
\text { in literacy rate will cause an increase in } \\
\text { life expectancy to } 2,439 \text { years. }\end{array}$ \\
\hline $\begin{array}{l}\text { Barlow and } \\
\text { Vissandjie (1999) }\end{array}$ & $\begin{array}{l}77 \text { countries } \\
1990\end{array}$ & $\begin{array}{l}\text { Multivariate cross } \\
\text { section analysis }\end{array}$ & $\begin{array}{l}\text { Literacy rate, per capita income and access } \\
\text { to safe water resources have been found to } \\
\text { have a significant positive impact on life } \\
\text { expectancy. The negative effects of } \\
\text { fertility and tropical location have been } \\
\text { revealed. In addition, it has been observed } \\
\text { that per capita consumption of animal } \\
\text { products has an inverse U relationship } \\
\text { with life expectancy. Per capita health } \\
\text { expenditure and urbanization rate were } \\
\text { found to be weak determinants. }\end{array}$ \\
\hline $\begin{array}{l}\text { Cremieux et al. } \\
\text { (1999) }\end{array}$ & $\begin{array}{l}\text { 10 Canadian provinces } \\
1978-1992\end{array}$ & Panel data regression & $\begin{array}{l}\text { Lifestyle factors were seen as the main } \\
\text { determinants of health. The positive } \\
\text { effect of income on life expectancy has } \\
\text { been found. } \\
\text { A } 10 \% \text { spending cut has been observed to } \\
\text { result in a 6-month reduction in life } \\
\text { expectancy for men and } 3 \text { month for } \\
\text { women }\end{array}$ \\
\hline $\begin{array}{l}\text { Elola et al. } \\
\text { (1995) }\end{array}$ & 17 European countries & $\begin{array}{l}\text { Cross-section data } \\
\text { regressions }\end{array}$ & $\begin{array}{l}\text { Health expenditures per capita may } \\
\text { explain more variance in infant mortality } \\
\text { than per capita GDP. Health spending is } \\
\text { inversely proportional to female } \\
\text { premature death and positively correlated } \\
\text { with life expectancy of women }\end{array}$ \\
\hline $\begin{array}{l}\text { Rogers and Wofford } \\
\text { (1989) }\end{array}$ & $\begin{array}{l}95 \text { least developed } \\
\text { countries }\end{array}$ & $\begin{array}{l}\text { Multiple regression } \\
\text { analysis }\end{array}$ & $\begin{array}{l}\text { It has been concluded that urbanization, } \\
\text { industrialization, education, access to safe } \\
\text { water, number of doctors and adequate } \\
\text { nutrition have an effect on life expectancy. }\end{array}$ \\
\hline $\begin{array}{l}\text { Auster et al. } \\
(1969)\end{array}$ & $\begin{array}{l}\text { USA } \\
1960\end{array}$ & $\begin{array}{l}\text { Two-stage least squares } \\
\text { and OLS method }\end{array}$ & $\begin{array}{l}\text { It was concluded that the impact of } \\
\text { environmental variables is higher than } \\
\text { health services. It was emphasized that } \\
\text { education reduces the mortality rate. }\end{array}$ \\
\hline Author & Country & Method & Findings \\
\hline
\end{tabular}


Following Salami et al. (2019), urbanization, carbon emissions, and water access were included as environmental variables.

The impact of urbanization on health status can be either positive or negative. Positive impact can be explained by fact that urban population has better medical cares, better education opportunities and improved socioeconomic infrastructure (Kalediene and Petrauskiene, 2000). Negative impact can be observed by the increase in slum settlements, poverty, ill-health and the decline in urban capital per person (Self and Grabowski, 2003).

Safe drinking water was found to be the main determinants of life expectancy in many researches (Macfarlane et al.2000; Gulis and Kross, 1999 among others). Access to safe and clean water will reduce disease that can occur because of bacteria and viruses. So it is expected that clean water will promote health outcomes of population (WHO/UNICEF, 2017).

It is well documented in the literature that increased level of carbon dioxide emissions will cause reduction in longevity (Balan, 2016; Ali and Ahmad, 2014). Empirical findings exerted that life expectancy is negatively correlated with environmental degradation (Rozehnalová et al.2021). Higher carbon dioxide emissions result in lungs, heart and cardiopulmonary system related health problems (Davidson, 2003). So it is anticipated that carbon emissions will reduce the lifespan.

The data were obtained from the World Bank database. Detailed information about the variables has been presented in Table 2. Variables were included into the model with their logarithms forms.

\section{Methodology and findings}

In this study, in order to determine the relationships between variables that are thought to affect the expected life expectancy of men and women, the Panel Autoregressive Distributed Lags (ARDL) model proposed by Pesaran et al.(1999) will be applied. For the estimation of the panel ARDL model, the following steps will be taken. First, it will be discussed whether there is a cross-sectional dependency between series. Then, panel unit root analysis will be employed in order to determine the integration order of the series.

Panel ARDL model can be employed when the series have different degrees of integration I (0) and I (1). It is a prerequisite for the series not to be integrated of order I(2) (Bhutto and Chang, 2018). It is appropriate to apply the panel ARDL model, as the variables are a mixture of $I(0)$ and I (1) series (Anjum et al.2017; Chang and Rajput, 2018). On the other hand, consistent results can be obtained in case of small sample sizes. Therefore, the panel ARDL
Table 2. Variables

\begin{tabular}{|c|c|c|}
\hline Variables & Abbreviation & Definition \\
\hline $\begin{array}{l}\text { Life expectancy } \\
\text { (female) }\end{array}$ & $\mathrm{LEX}_{\mathrm{f}}$ & $\begin{array}{l}\text { Life expectancy } \\
\text { at birth, female } \\
\text { (years) }\end{array}$ \\
\hline $\begin{array}{l}\text { Life expectancy } \\
\text { (male) }\end{array}$ & $\mathrm{LEX}_{\mathrm{m}}$ & $\begin{array}{l}\text { Life expectancy } \\
\text { at birth, male } \\
\text { (years) }\end{array}$ \\
\hline \multicolumn{3}{|c|}{ Economic variables } \\
\hline $\begin{array}{l}\text { Per capita } \\
\text { income }\end{array}$ & LGDP & $\begin{array}{l}\text { GDP per capita, } \\
\text { PPP (constant } \\
2017 \\
\text { international \$) }\end{array}$ \\
\hline $\begin{array}{l}\text { Health } \\
\text { expenditure }\end{array}$ & LHE & $\begin{array}{l}\text { Current health } \\
\text { expenditure }(\% \\
\text { of GDP) }\end{array}$ \\
\hline Unemployment & LUNEMP & $\begin{array}{l}\text { Unemployment } \\
\text { rate }\end{array}$ \\
\hline \multicolumn{3}{|c|}{ Environmental variables } \\
\hline Urbanization & LURBAN & $\begin{array}{l}\text { Urban } \\
\text { population }\end{array}$ \\
\hline $\begin{array}{l}\text { Access to safely } \\
\text { water }\end{array}$ & LWATER & $\begin{array}{l}\text { People using } \\
\text { safely managed } \\
\text { drinking water } \\
\text { services } \\
\text { (percentage of } \\
\text { population) }\end{array}$ \\
\hline $\begin{array}{l}\text { Carbon } \\
\text { emissions }\end{array}$ & $\mathrm{LCO} 2$ & $\begin{array}{l}\mathrm{CO}_{2} \text { emissions } \\
(\mathrm{kg} \text { per } 2010 \\
\mathrm{US} \$ \text { of GDP) }\end{array}$ \\
\hline
\end{tabular}

model emerges as a frequently used approach to reveal the long-term relationships between variables. In the first stage, it should be examined whether there is a cross-sectional dependency between the series. Cross-section independence indicates that the countries that make up the panel are not affected by a shock in any of the countries. Estimation results are greatly influenced by whether cross-sectional dependency is taken into consideration (Breusch and Pagan, 1980; Pesaran, 2004). In other words, it is extremely important to test whether there is a dependency between units, as the results obtained may be inconsistent (Menyah et al. 2014). For this purpose, the CD (Cross-Section Dependence) test proposed by Pesaran (2004) was utilized. Pesaran (2004) CD test results are summarized in Table 3.

According to the results summarized in Table 3, the null hypothesis was rejected because the probability values were less than 0.01 , and it was found that there was cross-sectional dependency in other series except urbanization variable. In case there is evidence for cross sectional dependence, it is recommended to apply second generation panel unit root tests. Accordingly, whether the series contain unit root or not was examined with the CADF (Cross-Sectionally Augmented Dickey Fuller) test proposed by Pesaran (2007). Pesaran (2007) suggested that the CADF test can be used effectively in both $\mathrm{T}>\mathrm{N}$ and $\mathrm{N}>\mathrm{T}$ situations. CADF regression equation can be estimated as follows: 
Table 3. Cross-section dependence test

\begin{tabular}{|c|c|c|}
\hline Variables & Test statistics & Probability \\
\hline LEXf & 42.48 & 0.000 \\
\hline LEXm & 41.63 & 0.000 \\
\hline LGDP & 42.92 & 0.000 \\
\hline LGDP 2 & 42.86 & 0.000 \\
\hline LUNEMP & 10.46 & 0.000 \\
\hline LURBAN & -0.06 & 0.948 \\
\hline LWATER & 38.48 & 0.000 \\
\hline LHE & 10.35 & 0.000 \\
\hline LCO2 & 23.17 & 0.000 \\
\hline
\end{tabular}

The test can be used in both cases when $\mathrm{T}>\mathrm{N}$ and $\mathrm{T}$ $<\mathrm{N}$. The test statistics can be calculated as follows in cases where

$$
\mathrm{T}>\mathrm{N}: C D=\sqrt{\frac{1}{N(N-1)}} \sum_{i=j}^{N-1} \sum_{i=j+1}^{N}\left(T \hat{\rho}_{i j}^{2}-1\right) \sim N(0,1) .
$$

Where $\rho_{i j}$ shows the simple correlation coefficient between the residuals obtained from the estimation of each equation using the least squares method. The null hypothesis, $H 0: \rho i j=\operatorname{cor}(u i t, u j t)=0 i \neq j$ implies that there no cross sectional dependenc among units.

$\Delta Y_{i t}=\alpha_{i}+b_{i} Y_{i, t-1} c_{i} \bar{Y}_{t-1}+d_{i} \Delta \bar{Y}_{t}+\varepsilon_{i t}$

Where $\bar{Y}_{t}$, refers to the average of all cross section observations over time. In the case of autocorrelation, the above equation can be expanded as follows:

$\Delta Y_{i t}=\alpha_{i}+\rho_{i}^{*} Y_{i t-1}+d_{0} \bar{Y}_{t-1}+\sum_{j=0}^{p} d_{j+1} \Delta \bar{Y}_{t-j}+$ $\sum_{k=1}^{p} c_{k} \Delta Y_{i, t-k}+\varepsilon_{i t}$

CIPS (Cross-Sectional Augmented Im-PesaranShin) statistic was estimated as follows:

CIPS $=\frac{1}{N} \sum_{i=1}^{N} C A D F_{i}$

Where $C A D F_{i}$ indicates the means of the t-statistics of the lagged variables. The Levin-Lin Chu (LLC, 2002) unit root test, one of the first generation unit root tests, was applied to urbanization variable. LLC (2002) $\mathrm{t}$ test statistics can be obtained as follows under the null hypothesis $\delta=0$ :

$t_{\delta}=\frac{\widehat{\delta}}{\operatorname{std}(\widehat{\delta})}$

(Pesaran (2007) and LLC (2002) unit root test results are presented in Table 4 .

According to the results it $\mathrm{cn}$ be concluded that other variables except LURBAN are not stationary at level. In other words, it is seen that the variables are a mixture of $I(0)$ and I (1) series. In this case, the relationship between the variables will be examined by utilizing the Panel ARDL model proposed by Pesaran et al. (1999). This procedure can be applicable to examine both the short and long-run relationships between the variables. In other words, via panel ARDL model can be obtained both short and long run properties of a model. Moreover, the advantage of implementing panel ARDL model with sufficient lags is a elimination of the issue of endogeneity (Pesaran and Smith, 1999). In addition, it is stressed that abovementioned procedure is efficient to capture the long-run relationship in case of small sample sizes.

Panel ARDL model, which assess the relationship between life expectancy and its determinants can be expressed as follows:
Table 4. Results of panel unit root tests

\begin{tabular}{|c|c|c|c|c|}
\hline & $\begin{array}{l}\text { t bar } \\
\text { statis- } \\
\text { tics }\end{array}$ & $\begin{array}{l}\text { z bar } \\
\text { statis- } \\
\text { tics }\end{array}$ & $\begin{array}{c}\text { Probabil- } \\
\text { ity }\end{array}$ \\
\hline & & \multicolumn{3}{|c|}{ Level } \\
\hline \multirow{17}{*}{$\begin{array}{l}\text { Pesa } \\
\text {-ran } \\
\text { unit } \\
\text { root }\end{array}$} & LEX $_{\mathrm{f}}$ & -2.613 & -1.318 & 0.094 \\
\hline & $\mathrm{LEX}_{\mathrm{m}}$ & -2.038 & 0.958 & 0.831 \\
\hline & LGDP & -1.977 & 1.199 & 0.885 \\
\hline & LGDP $^{2}$ & -1.986 & 1.165 & 0.878 \\
\hline & LUNEMP & -1.477 & 3.181 & 0.999 \\
\hline & LWATER & -1.951 & 1.303 & 0.904 \\
\hline & LHE & -1.717 & 2.229 & 0.987 \\
\hline & $\mathrm{LCO} 2$ & -2.364 & -0.332 & 0.370 \\
\hline & \multicolumn{4}{|c|}{ First Difference } \\
\hline & $\Delta \mathrm{LEX}_{\mathrm{f}}$ & $\begin{array}{c}-3.438 \\
*\end{array}$ & $-4.585^{*}$ & 0.000 \\
\hline & $\Delta \mathrm{LEX}_{\mathrm{m}}$ & $\begin{array}{c}-3.620 \\
*\end{array}$ & $\begin{array}{c}-5.307 \\
*\end{array}$ & 0.000 \\
\hline & $\Delta \mathrm{LGDP}$ & $-2.497^{*}$ & $-3.007^{*}$ & 0.001 \\
\hline & $\Delta \mathrm{LGDP}^{2}$ & $-2.464 *$ & $-2.880^{*}$ & 0.000 \\
\hline & $\begin{array}{l}\Delta \mathrm{LUNN}- \\
\text { EMP }\end{array}$ & $-2.951^{*}$ & $-4.786^{*}$ & 0.000 \\
\hline & $\begin{array}{l}\triangle \mathrm{LWA}- \\
\text { TER }\end{array}$ & $-2.767^{*}$ & $-4.068^{*}$ & 0.000 \\
\hline & $\Delta \mathrm{LHE}$ & $-3.527 *$ & $-7.047^{*}$ & 0.000 \\
\hline & $\Delta \mathrm{LCO} 2$ & $-2.688^{*}$ & $-3.756^{*}$ & 0.000 \\
\hline & & $\begin{array}{c}\mathbf{t} \\
\text { statis- } \\
\text { tics } \\
\end{array}$ & & $\begin{array}{l}\text { Probabil- } \\
\text { ity }\end{array}$ \\
\hline $\begin{array}{l}\text { LL } \\
\text { C }\end{array}$ & LURBAN & $2.6692 *$ & & 0.003 \\
\hline \multicolumn{5}{|c|}{$\begin{array}{l}\text { The null hypothesis implies that there is unit root, the } \\
\text { series is not stationary. } \\
* \text { denotes for } 1 \% \text { significance level. }\end{array}$} \\
\hline
\end{tabular}

Where $\gamma$ and $\delta$ denote the short-run coefficients, $\beta$ long-run coefficients, and $\theta$ error correction term. LEX is the dependent variable. $X$ is a set of explanatory variables. A negative and significant coefficient of the error correction term implies evidence of long-run relationship between variables. Equation (5) is estimated with the help of Pooled Mean Group (PMG) and Mean Group (Mean Group, MG) estimators. Pooled mean group estimator assumes the long-run parameters the same for all units, while allowing the short-term coefficients to differ from unit to unit (Pesaran et al. 1997). The main feature of using PMG is that the PMG is less susceptible to the existence of outliers for a relatively small cross-section of data. PMG estimators are applied to predict long-term coefficients, to capture the pooling behavior of homogeneity constraints and short-term coefficients by the average across units used to derive the means of predicted errorcorrection coefficients and other short-term parameters (Pesaran et al. 1999).

Mean group estimator allows the constant term, slope coefficients and error variances to change from unit to unit (Pesaran et al. 1999). In other words, long-term and short-term parameters can differ 
across units. Estimator requires a large enough $\mathrm{N}$ and $\mathrm{T}$ in order to obtain consistent outcomes. This estimator has some shortcomings. The drawback of MG estimator is that it does not take cross-sectional dependence into account. We will apply both estimators. Hausman test (1978) was employed in order to choose between two estimators. PMG estimator is preferred according to Hausman test results. Accordingly, the estimation results obtained by the pooled mean group estimator are presented in Table 5.

Table 5. Pooled mean group estimation results

\begin{tabular}{|c|c|c|}
\hline & Model 1 & Model 2 \\
\hline & 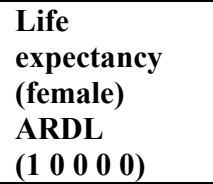 & 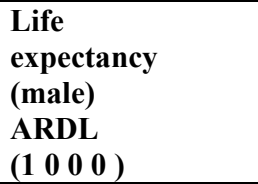 \\
\hline \multicolumn{3}{|c|}{ Long-Run Coefficients } \\
\hline LGDP & $\begin{array}{l}0.6002 * \\
(0.1080) \\
\end{array}$ & $\begin{array}{l}2.2056^{*} \\
(0.6607) \\
\end{array}$ \\
\hline LGDP $^{2}$ & $\begin{array}{l}-0.0314^{*} \\
(0.0059)\end{array}$ & $\begin{array}{l}-0.1066^{*} \\
(0.0323)\end{array}$ \\
\hline LUNEMP & $\begin{array}{l}-0.0065^{*} \\
(0.0016) \\
\end{array}$ & \\
\hline $\mathrm{LCO} 2$ & $\begin{array}{l}-0.0146^{*} \\
(0.0033) \\
\end{array}$ & $\begin{array}{l}-0.0577^{*} \\
(0.0096) \\
\end{array}$ \\
\hline LURBAN & $\begin{array}{l}0.3314^{*} \\
(0.0233)\end{array}$ & \\
\hline LWATER & $\begin{array}{l}0.0361^{*} \\
(0.0051) \\
\end{array}$ & $\begin{array}{l}0.1127 * \\
(0.0093)\end{array}$ \\
\hline LHE & & $\begin{array}{l}0.0609^{*} \\
(0.0091)\end{array}$ \\
\hline \multicolumn{3}{|c|}{ Short Run Coefficients } \\
\hline $\begin{array}{l}\text { Error } \\
\text { correction } \\
\text { term }\end{array}$ & $\begin{array}{l}-0.3598^{*} \\
(0.1288)\end{array}$ & $\begin{array}{l}-0.2592 * * \\
(0.1024)\end{array}$ \\
\hline$\Delta$ LGDP & $\begin{array}{l}-1.0674 \\
(1.1716)\end{array}$ & $\begin{array}{l}2.0591 \\
(3.3004)\end{array}$ \\
\hline$\Delta \mathrm{LGDP}^{2}$ & $\begin{array}{c}0.0462 \\
(0.0587) \\
\end{array}$ & $\begin{array}{l}-0.1084 \\
(0.1621) \\
\end{array}$ \\
\hline$\triangle \mathrm{LUUNEMP}$ & $\begin{array}{l}-0.0084 \\
(0.0130)\end{array}$ & \\
\hline$\Delta \mathrm{LCO} 2$ & $\begin{array}{l}-0.0080^{* * *} \\
(0.0043)\end{array}$ & $\begin{array}{l}0.0011 \\
(0.0063)\end{array}$ \\
\hline$\triangle \mathrm{LURBAN}$ & $\begin{array}{l}0.5014 \\
(0.5762)\end{array}$ & \\
\hline$\triangle$ LWATER & $\begin{array}{l}0.7246 \\
(0.7995) \\
\end{array}$ & $\begin{array}{l}0.3911 \\
(1.2038)\end{array}$ \\
\hline$\Delta \mathrm{LHE}$ & & $\begin{array}{l}-0.0076 \\
(0.0070) \\
\end{array}$ \\
\hline Constant & $\begin{array}{r}-1.3982^{*} \\
(0.5092) \\
\end{array}$ & $\begin{array}{l}-2.0169^{* *} \\
(0.7995)\end{array}$ \\
\hline \multicolumn{2}{|c|}{$\begin{array}{l}\text { Hausman Test } \\
\mathrm{chi}^{2}=0.09 \quad \text { Prob }>\text { chi }^{2}=1.000\end{array}$} & $\begin{array}{l}\text { chi }^{2}=7.07 \\
\text { Prob }>\text { chi }^{2}=0.2155\end{array}$ \\
\hline \multicolumn{2}{|c|}{$\begin{array}{l}\text { Log Likelihood } \\
1370.076\end{array}$} & 1242.233 \\
\hline \multicolumn{2}{|c|}{ Number of observations } & 256 \\
\hline \multicolumn{3}{|c|}{$\begin{array}{l}*, * * \text { and } * * * \text { denotes significance level for } 1 \%, 5 \% \text {, } \\
\text { and } 10 \% \text {, respectively. } \\
\text { Standard errors are given in parentheses. }\end{array}$} \\
\hline
\end{tabular}

According to the pooled mean group estimation results, the long-term coefficients of all variables for both models were found to be statistically significant at the $1 \%$ level.

Error correction terms were found to be negative (0.35 and -0.25 ) and statistically significant in both models. This indicates that approximately $35 \%$ and $25 \%$ of the shock that occur in one period will recover in the next period, respectively. In other words, it confirms a stable long-run relationship between the variables.

For the income variable the coefficient of income is found to be positive and significant while the coefficient of income square is negative and significant. It specifies that life expectancy initially rise as income increases and then begin to decline. It is noteworthy, that the magnitude of escalation in emissions associated with urbanization is higher than the potential reduction. The magnitude of the health effect of income is greater compared to other variables. In other words, it implies a strong relationship between income and life expectancy. This findings are in good accordance with those of Pritchett and Summers (1996), Pritchett and Viarengo (2010), and Jetter et al.(2019).

We find unemployment has a long-run negative and statistically significant impact on life expectancy, implying that unemployment decreases life expectancy of women. This outcome corroborates with the findings of Tafran et al. (2020).

For the carbon emissions variable, the long run coefficients are negative and significant at the one percent level. We found a long-run coefficient of carbon emissions -0.01 and -0.05 for women and men, respectively. A $1 \%$ increase in carbon emissions decreases life expectancy of women and men by $0.01 \%$ and $0.05 \%$, respectively. These results are consistent with several researchers including the study Ahmad et al. (2018) and Matthew et al. (2018) among others.

The results indicate a positive and significant relationship between urbanization and life expectancy, suggesting that higher urbanization lead to higher life expectancy. This result of a positive relationship supports the findings of Monsef and Mehrjardi (2018).

Estimates indicate that a $1 \%$ increase in access to safe water leads to an increase in life expectancy of women and men by $0.03 \%$ and $0.11 \%$, respectively. These results are in line with several studies, such as McCarthy and Wolf (2001), Heysen and Musgrove (1986), and Gullis (2000).

The health expenditure coefficient 0.06 , suggests that $1 \%$ increase in health expenditure results in an increase of about $0.06 \%$ in life expectancy. This result is consistent with the findings of Novignon et al. (2012), Heijink et al. (2013), Rahman et al. (2018), and Bein et al.(2017) among others.

If we evaluate the findings in general, it is seen that economic and environmental factors have different effects on the life expectancy of men and women. The magnitude of above mentioned factors are greater in volume for men than for women. 


\section{Conclusion}

In this study, socioeconomic and environmental factors affecting the life expectancy of men and women in 16 selected transition economies were examined. For this purpose the Panel ARDL model was applied to the annual data of the countries considered for the period 2000-2016.

Results revealed that all explanatory variables (income, unemployment, health expenditures, urbanization, carbon emissions, and access to safe drinking water) significantly affect the life expectancy of women and men. When the socioeconomic and environmental factors discussed in the study were evaluated in terms of gender, it was seen that they were different for women and men. It has been found that above-mentioned factors are more effective on life expectancy of men than women in selected transition economies.

In the light of these findings, priority should be given to improving socioeconomic and environmental factors while making decisions to promote and improve the health of women and men. In other words, it can be said that health outcomes can be improved by providing the population with safe and accessible drinking water and giving the necessary importance to income, urbanization and health expenditures.

In our study, findings were obtained that support the view that the increase in the carbon emissions reduce the longevity. In other words, environmental quality is a very important factor affecting health. Therefore, it can be said that environmental policy is necessary in the countries considered. In general, it is recommended to prioritize socioeconomic and environmental targets in the health policies of countries.

Acknowledgement. Previous version of this paper was presented in International Conference on Different Aspects of Health held on November 12-14, 2020 in Turkey.

\section{References}

1. AFONSO A., AUBYN M. St., 2006, Relative Efficiency of Health Provision: a DEA Approach with Non-Discretionary Inputs, ISEG-UTL Economics Working Paper, No. 33/2006/DE/UECE, www. iseg.utl.pt/departamentos/economia/wp/wp332006de uece.pdf.

2. AHN N., GARCIA J. R., JIMENO J. F., 2004, The Impact of Unemployment on Individual Well-Being in the EU, NEPRI Working Paper, 29: 1-19.

3. AHMAD M., UR RAHMAN Z., HONG L., KHAN S., KHAN Z., NAEEM K. M., 2018, Impact of Environmental Quality Variables and Socio Economic Factors on Human Health: Empirical Evidence from China, Pollution, 4(4): 571-579.

4. ALI A., AHMAD K., 2014, The impact of socio-economic factors on life expectancy for sultanate of Oman: An Empirical Analysis, Middle-East Journal of Scientific Research, 22(2): 218-224.
5. ANJUM N., GHUMRO N. H., HUSAIN B., 2017, Asymmetric Impact of Exchange Rate Changes on Stock Prices: Empirical Evidence from Germany, International Journal of Economics and Financial Research, 3(11): 240-245.

6. ASAFU-ADJAYE J., 2007, Income Inequality and Health: a Multi-Country Analysis, International Journal of Social Economics, 31(1): 195-207. DOI: 10.1108/03068290410515501.

7. ASISKOVITCH S., 2010, Gender and Health Outcomes: The Impact of Healthcare Systems and Their Financing on Life Expectancies of Women and Men, Social Science and Medicine, 70(6): 886-895.

8. AUSTER R., LEVESON I., SARACHEK S., 1969, The Production of Health: An Exploratory Study, Journal of Human Resources, 4: 411-436.

9. BALAN F., 2016, Environmental Quality and its Human Health Effects: A Causal Analysis for the EU25, International Journal of Applied Economics, 13(1): 57-71.

10. BARLOW R., VISSANDJÉE B., 1999, Determinants of National Life Expectancy, Canadian Journal of Development Studies, 20(1): 9-29.

DOI: 10.1080/02255189.1999.9668787.

11. BAYATI M., AKBARIAN R., KAVOSI Z., 2013, Determinants of Life Expectancy in Eastern Mediterranean Region: A Health Production Function, International Journal of Health Policy and Management, 1: 1-7.

12. BEIN M.A., UNLUCAN D., OLOWU G., KALIFA W., 2017, Healthcare spending and health outcomes: evidence from selected east African countries, Afr Health Sci., 17(1): 247-254.

13. BILAS V., FRANC S., BOŠNJAK M., 2014, Determinant Factors of Life Expectancy, Collegium Antropologicum, 38(1): 1-9.

14. BHUTTO N.A., CHANG B.H., 2018, The Effect of the Global Financial Crisis on the Asymmetric Relationship Between Exchange Rate and Stock Prices, High Frequency, 2: 175-183.

15. BLAZQUEZ-FERNÁNDEZ C., CANTAREROPRIETO D., PASCUAL SAEZ M., 2017, Health Expenditure and Socio-Economic Determinants of Life Expectancy in the OECD Asia/Pacific Area Countries, Applied Economics Letters, 24(3): 167-169. DOI: $10.1080 / 13504851.2016 .1173174$

16. BOLTON K.L., RODRIGUEZ E., 2009, Smoking, Drinking and Body Weight After Re-Employment: Does Unemployment Experience and Compensation Make a Difference ?, BMC Public Health 9: 77. DOI: 10.1186/1471-2458-9-77.

17. BREUSCH T. S., PAGAN A. R., 1980, The Lagrange Multiplier Test and its Applications to Model Specification in Econometrics, The Review of Economic Studies, 47(1): 239-253. DOI: $10.2307 / 2297111$.

18. CASE A., LUBOTSKY D., PAXSON C., 2002, Economic status and health in childhood: the origins of the gradient, American Economic Review, 92(5): 1308-1334.

19. CHANG B. H., RAJPUT S. K. O., 2018, Do the Changes in Macroeconomic Variables Have a Symmetric or Asymmetric Effect on Stock Prices? Evidence from Pakistan, South Asian Journal of Business Studies, 7(3): 312-331.

DOI: 10.1108/SAJBS-07-2018-0077. 
20. CHIRESHE J., OCRAN M.K., 2020, Health Care Expenditure and Health Outcomes İn Sub-Saharan African Countries, African Development Review, 32(3). DOI: 10.1111/1467-8268.12444.

21. CORNIA G. A., PANICCIA R., 2000, The Transition Mortality Crisis: Evidence, İnterpretation, and Policy Responses, The Mortality Crisis In Transitional Economies, eds. Cornia G.A. and Paniccia R., Oxford University Press, Oxford, p. 337.

22. COCKERHAM W. C, HINOTEA B. P., ABBOTT P., 2006, Psychological Distress, Gender, and Health Lifestyles in Belarus, Kazakhstan, Russia, and Ukraine, Social Science and Medicine, 63: 23812394.

23. CRÉMIEUX P.-Y., OUELLETTE P., PILON C., 1999, Health Care Spending as Determinants of Health Outcomes, Health Economics, 8: 627-639.

24. CHRIS JAMES M.D., FRANCO S., 2017, Inclusive Growth and Health, OECD Heal Work Pap. 103. DOI: $10.1787 / 93 \mathrm{~d} 52 \mathrm{bcd}-\mathrm{en}$.

25. D'ARCY C., 1986, Unemployment and Health: Data and Implications, Can J Pub Health, May/June, 77: 124-131.

26. DAVIDSON C., 2003, Marine Notice: Carbon Dioxide: Health Hazard, Australian Maritime Safety Authority.

27. DEATON A. S., 2002, Policy Implications of Gradient of Health and Wealth, Health Affairs, 21: 13-30.

28. DEAN J. A., WILSON K., 2009, Education? It is Irrelevant to My Job Now; It Makes Me Very Depressed: Exploring the Health Impacts of under/Unemployment among Highly Skilled Recent Immigrants in Canada, Ethnicity and Health, 14(2): 185204.

29. DEW M.A., BROMET E.J., PENKOWER L., 1992, Mental Health Effects of Job Loss in Women, Psychol Med, 22(3): 751-764.

30. DE VOGLI R., MISTRY R, GNESOLTO R., CORNIA G.A., 2005, Has the relation between income inequality and life expectancy disappeared? Evidence from Italy and top industrialised countries, $J$ Epidemiol Community Health, 59(2): 158-162. DOI: $10.1136 /$ jech.2004.020651.

31. DOOLEY D., CATALANO R., ROOK, K.S. 1988, Personal and Aggregate Unemployment and Psychological Symptoms, Journal of Social Issues, 44: 107123.

DOI: 10.1111/j.1540-4560.1988.tb02094.x.

32. DRASTICHOVÁ M., FILZMOSER P. 2020, The Relationship Between Health Outcomes and Health Expenditure in Europe by Using Compositional Data Analysis, Problemy Ekorozwoju/ Problems of Sustainable Development, 15(2): 99-110.

33. ELO I.T., PRESTON S.H., 1992, Effects of EarlyLife Conditions on Adult Mortality: A Review, Population Index, 58(2): 186-212.

34. ELOLA F.J., DAPONTE A., NAVARRO V., 1995, Health Indicators and the Organisation of Healthcare Systems in Western Europe, American Journal of Public Health,85(10): 1397-1401. DOI: 10.2105/AJPH.85.10.1397

35. EVANS M.F., SMITH V.K., 2005, Do New Health Conditions Support Mortality-Air Pollution Effects?, Journal of Environmental Economics and Management, 50: 496-518.
36. FABELLA C., 2008, Population Growth and Infant Mortality, UPSE Discussion Paper No. 2008, 10, University of the Philippines, School of Economics (UPSE), Quezon City.

37. FAYISSA B., GUTEMA P., 2005, Estimating a Health Production Function for Sub Saharan Africa (SSA), Applied Economics, 37: 155-164.

38. GRIGORIEV P., SHKOLNIKOV V., ANDREEV E., JASILIONIS D., JDANOV D., MESLÉ F., VALLIN J., 2010, Mortality in Belarus, Lithuania, and Russia: Divergence in Recent Trends and Possible Explanations La mortalité en Biélorussie, Lituanie et Russie: Divergence dans les Tendances Récentes et Explications Possibles, European Journal of Population / Revue Européenne de Démographie, 26(3): 245-274.

39. GULIS G., KROSS B.C., 1999, Drinking water, mortality, and life expectancy: an assessment of the east-west mortality gap in Europe, Cent Eur J Public Health, 7(4): 191-196.

40. GULIS G. 2000, Life Expectancy as an Indicator of Environmental Health, European Journal of Epidemiology 16: 161-165. DOI: 10.1023/A:1007629306606.

41. HAUSMAN J. A., 1978, Specification Tests in Econometrics, Econometrica, 46(6): 1251-1271.

42. HEIJINK R., KOOLMAN X., WESTERT G.P., 2013, Spending More Money, Saving More Lives? The Relationship Between Avoidable Mortality and Healthcare Spending In 14 Countries, Eur J Health Econ 14: 527-538. DOI: 10.1007/s10198-012-0398-3.

43. Health in the Framework of Sustainable Development, 2014, Technical Report for the Post-2015 Development Agenda.

44. HERZER D., NUNNENKAMP P., 2012, FDI and Health in Developed Economies: A Panel Cointegration Analysis, Working Paper No. 1756, Kiel Institute for the World Economy, Kiel.

45. HEYSEN S., MUSGROVE P., 1986, Interdepartmental Differences in Life Expectancy at Birth in Peru as It Relates to Income, Household DrinkingWater, and Provision of Medical Consultations, PAHO Bull., 20(1) :31-44.

46. HSIAO W.C., 2004, Disparity in Health: The UnderBelly of China's Economic Development, Harvard China Rev, 5(1): 64-70.

47. JETTER M., LAUDAGE S., STADELMANN D., 2019, The Intimate Link Between Income Levels and Life Expectancy: Global Evidence from 213 Years, Social Science Quarterly, 100(4): 1387-1403.

48. IVASCHENKO O., 2005, The Patterns and Determinants of Longevity in Russia's Regions: Evidence from Panel Data, Journal of Comparative Economics, 33 (4): 788-813.

49. KALEDIENE R., PETRAUSKIENE J., 2000, Regional Life Expectancy Patterns in Lithuania, European Journal of Public Health, 10: 101-104.

50. KARAMAN S., ÜREK D., BILGIN DEMIR İ., UĞURLUOĞLU Ö., IŞIK O., 2020, The Impacts of Healthcare Spending on Health Outcomes: New Evidence from OECD Countries, Erciyes Med J., 42(2): 218-222.

51. KOBZA J., GEREMEK M., 2015, Exploring the Life Expectancy Increase in Poland in the Context of CVD Mortality Fall: The Risk Assessment Bottom-Up Approach, From Health Outcome to Policies, 
INQUIRY: The Journal of Health Care Organization, Provision, and Financing, 1-12.

52. KORBELIUS V., PAULUS M., TROCH T., 2016, Life Expectancy and its Determinants in the Czech Republic, IES Working Paper 06.

53. LAVIS J.N., 1998, Unemployment and Mortality: A Longitudinal Study in the United States, 1968-1992, Centre for Health Economics and Policy Analysis Working Paper Series 05, Centre for Health Economics and Policy Analysis (CHEPA), McMaster University, Hamilton, Canada.

54. LEVIN A., LIN C.F., CHU C.J., 2002, Unit Root Tests in Panel Data: Asymptotic and Finite-Sample Properties, Journal of Econometrics, 108(1): 1-24.

55. LICHTENBERG F. R., 2002, Sources of U.S. Longevity Increase, 1960-1997, NBER Working Paper No. 8755.

56. LLERAS-MUNEY A., 2005, The Relationship Between Education and Adult Mortality in the United States, The Review of Economic Studies, 72(1): 189221. DOI: $10.1111 / 0034-6527.00329$.

57. LOEF M., WALACH H., 2012, The Combined Effects of Healthy Lifestyle Behaviors an all-Cause Mortality: A Systematic Review and Metaanalysis, Preventive Medicine, 55: 163-170.

58. LUY M., WEGNER-SIEGMUNDT C., 2015, The Impact of Smoking on Gender Differences in Life Expectancy: More Heterogeneous than Often Stated, European Journal of Public Health, 25: 706-710.

59. LUY M., ZANNELLA M., WEGNER-SIEGMUNDT C., MINAGAWA Y., LUTZ W., CASELLI G., 2019, The Impact of Increasing Education Levels on Rising Life Expectancy: A Decomposition Analysis for Italy, Denmark, and the USA, Genus, 75(11). DOI: 10.1186/s41118-019-0055-0.

60. MACFARLANE S., RACELIS M., MULI-MUSIIME F., 2000, Public Health In Developing Countries, Lancet, 356(2): 841-846.

61. MADDISON PROJECT DATABASE, 2020, https:// www.rug.nl/ggdc/historicaldevelopment/maddison/ releases/maddison-project-database-2020?lang=en.

62. MCKEE-RYAN F., SONGZ., WANBERG C.R., KINICKI A.J., 2005, Psychological and physical wellbeing during unemployment: a meta-analytic study, $J$ Appl Psychol, 90(1): 53-76.

DOI: $10.1037 / 0021-9010.90 .1 .53$.

63. MARIANI F., PÉREZ-BARAHONA A., RAFFIN R., 2009, Life Expectancy and the Environment, IZA Discussion Paper No. 4564.

64. MARMOT M., WILKINSON R. 2003, The Solid Facts (2th Ed.), World Health Organization, Geneva.

65. MATTHEW P., BRODERSEND.M., 2018, Income Inequality and Health Outcomes in the United States: An Empirical Analysis, The Social Science Journal, 55(4), 432-442. DOI: 10.1016/j.soscij.2018.05.001.

66. MATTHEW O., OSABOHIEN R., FAGBEMINIYI F., FASINA A., 2018, Greenhouse Gas Emissions and Health Outcomes in Nigeria: Empirical Insight from Auto regressive Distribution Lag Technique, International Journal of Energy Economics and Policy, 8 (3): 43-50.

67. MCCARTHY F., WOLF H., 2001, Comparative Life Expectancy in Africa, Policy Research Working Paper.

68. MEDAS G., 2015, Roma and Health: The Social Determinants of Health: Lessons from the Case of
Roma in Hungary, Journal for Labour and Social Affairs in Eastern Europe, 18(2): 149-173.

69. MILADINOV G., 2020, Socioeconomic Development and Life Expectancy Relationship: Evidence from the EU Accession Candidate Countries, Genus, 76(2). DOI: 10.1186/s41118-019-0071-0.

70. MENYAH K., NAZLIOĞLU Ş., WOLDE-RUFAEL Y., 2014, Financial Development, Trade Openness and Economic Growth in African Countries: New Insights from a Panel Causality Approach, Economic Modelling, 37: 386-394.

71. MOHAMMED A.J., GHEBREYESUS T.A., 2018, Healthy Living, Well-Being and the Sustainable Development Goals, Bulletin of the World Health Organization, 96: 590-590A. DOI: 10.2471/BLT.18.222042.

72. MONSEF A., MEHRJARDI A.S., 2018, Effect of Unemployment on Health Capital, Iran. Econ. Rev. 22(4): 1016-1033.

73. NIXON J., ULMAN P., 2006, The Relationship between Health Care Expenditure and Health Outcomes, The European Journal of Health Economics, 7(1),7-18. DOI: 10.1007/s10198-005-0336-8.

74. NOELKE C., BECKFIELD J., 2014, Recessions, Job Loss, and Mortality Among Older US Adults, American Journal of Public Health, 104(11): e126-e134. DOI: 10.2105/AJPH.2014.302210.

75. NOLTE E., MCKEE M., GILMORE A., 2005, Morbidity and Mortality in Transition Countries of Europe, The New Demographic Regime: Population Challenges and Policy Responses, eds. Macura M., MacDonald A., Haug W., United Nations.

76. NORSTRÖM F., JANLERT U., HAMMARSTRÖM A., 2017, Is Unemployment in Young Adulthood Related to Self-Rated Health Later in Life? Results from the Northern Swedish Cohort, BMC Public Health, 17(1): 529.

77. NOVIGNON J., OLAKOJO S.A., NONVIGNON J., 2012, The Effects of Public and Private Health Care Expenditure on Health Status in Sub-Saharan Africa: New Evidence from Panel Data Analysis, Heal Econ Rev., 2(22).

78. OKSUZYAN A., JUEL K., VAUPEL J.W., CHRISTENSEN K., 2008, Men: Good Health and High Mortality. Sex Differences in Health and Aging, $A g$ ing Clinical and Experimental Research, 20: 91-102.

79. OR Z. 2000a, Determinants of Health Outcomes in Industrialised Countries: A Pooled, Cross-country, Time Series Analysis, OECD Economic Studies, 30, 2000/I.

80. OR Z. 2000b, Exploring the Effects of Health Care on Mortality Across OECD Countries, OECD Labour Market and Social Policy, Occasional Paper No. 46.

81. Our World in Data, 2021, https://ourworldindata. org/.

82. OWEN A.L., WU S., 2007, Is Trade Good for Your Health? Review of International Economics, 15(4): 660-682.

83. PASICHNYI M., NEPYTALIUK A. 2021, The Contributions of Demographic Factors to Economic Growth, Problemy Ekorozwoju/Problems of Sustainable Development, 16(1): 219-229

84. PESARAN M. H., SHIN Y., SMITH R.P., 1997, Pooled Estimation of Long-Run Relationships in Dynamic Heterogeneous Panels, University of Cambridge, Department of Applied Economics. 
85. PESARAN M. H., SHIN Y., SMITH R.P., 1999, Pooled Mean Group Estimation of Dynamic Heterogeneous Panels, Journal of the American Statistical Association, 94(446): 621-634.

86. PESARAN M. H., SHIN Y. 1999, An Autoregressive Distributed-Lag Modelling Approach to Cointegration Analysis, Econometrics and Economic Theory in the 20th Century, ed. Strom S., p. 371-413.

87. PESARAN H., 2004, General Diagnostic Tests for Cross Section Dependence in Panels, Working Paper No 0435, University of Cambridge.

88. PESARAN M. H., 2007, A Simple Panel Unit Root Test in the Presence of Cross-section Dependence, Journal of Applied Econometrics, 22: 265-312.

89. PINKHASOV R.M., SHTEYNSHLYUGER A., HAKIMIAN P., LINDSAY G.K., SAMADI D.B., SHABSIGH R., 2010, Are Men Shortchanged On Health? Perspective on Life Expectancy, Morbidity, and Mortality in Men and Women in the United States, International Journal of Clinical Practice, 64: 465-474.

DOI:10.1111/j.17421241.2009.02289.x.

90. PRITCHETT L., SUMMERS L.H., 1996, Wealthier is Healthier, Journal of Human Resources 31(4): 841868.

91. PRITCHETT L., VIARENGO M., 2010, Explaining the Cross-National Time Series Variation in Life Expectancy: Income, Women's Education Shifts and What Else?, UNDP, Washington, DC.

92. RAHMAN M.M., KHANAM R., RAHMAN A., 2018, Health Care Expenditure and Health Outcome Nexus: New Evidence from the SAARC-ASEAN Region, Globalization and Health, 14: 113.

93. ROGERS R. G., WOFFORD S., 1989, Life Expectancy in Less Developed Countries: Socio-Economic Development or Public Health? Journal of Biosocial Science, 21: 245-252.

94. ROZEHNALOVÁ H., MÁDR M., FORMANOVÁ L., ANDRLIK B. 2021, Influence of Pollutants from Transport on Life Expectancy in the EU Countries, Problemy Ekorozwoju/ Problems of Sustainable Development, 16(1): 209-217.

95. SALAHUDDIN M., VINK N., RALPH N., GOW J., 2020, Effects of Economic Growth, Foreign Direct Investment and Internet Use on Child Health Outcomes: Empirical Evidence from South Africa, Development Studies Research, 7(1): 1-17. DOI: 10.1080/21665095.2020.1717362.

96. SALAMI D., SHAABAN A.N., MARTINS M.R.O., 2019, Africa Rising, a Narrative for Life Expectancy Gains? Evidence from a Health Production Function, Annals of Global Health, 85(1): 1-10. DOI: https://doi.org/10.5334/aogh.2307.

97. SEDE P., OHEMENG W., 2015, Socio-Economic Determinants of Life Expectancy in Nigeria (1980 2011), Health Economics Review, 5(2): 1-11. DOI: 10.1186/s13561-014-0037-z.

98. SELF S., GRABOWSKI R., 2003, How Effective is Public Health Expenditure in Improving Overall Health? A Cross-Country Analysis, Appl Econ. 35(7): $835-845$.

DOI: $10.1080 / 0003684032000056751$.

99. QUT Queensland University of Technology 2015, Unclean Water Supply May Contribute to Lower Life
Expectancy in Remote Australia, https://phys.org/ news/2015-12-unclean-contribute-liferemote-australi a.html.

100. SHARMA R., 2018, Health and Economic Growth: Evidence from Dynamic Panel Data of 143 Years, PLoS ONE, 13(10): e0204940. DOI: 10.1371/journal.pone.0204940.

101. SHAW J. W., HORRACE W. C., VOGEL R. J., 2005, The Determinants of Life Expectancy: An Analysis of the OECD Health Data, Southern Economic Journal, 71: 768-873.

102. SMITH J. P., 1999, Healthy Bodies and Thick Wallets: The Dual Relation between Health and Economic Status, Journal of Economic Perspectives, 13(2): 145-166. DOI: 10.1257/jep.13.2.145.

103. SOARES R.R., 2007, Health and the Evolution of Welfare across Brazilian Municipalities, Journal of Development Economics, 84: 590-608.

104. STENGOS T., THOMPSON B. S., WU X. 2008, The Evolution of the Conditional Joint Distribution of Life Expectancy and Per Capita Income Growth, Economics Publications and Research, Paper 44. http:// digitalcommons.ryerson.ca/economics/44.

105. SUNDBERG L., AGAHI N., FRITZELL J., FORS S., 2018, Why is the Gender Gap in Life Expectancy Decreasing? The Impact of Age- and Cause-Specific Mortality in Sweden 1997-2014, International Journal of Public Health, 63: 673-681. DOI: $10.1007 / \mathrm{s} 00038-018-1097$.

106. TAFRAN K., TUMIN M., OSMAN A.F., 2020, Poverty, Income, and Unemployment as Determinants of Life Expectancy: Empirical Evidence from Panel Data of Thirteen Malaysian States, Iran J Public Health, 49(2): 294-303.

107. TAVARES A.I., 2017, Infant Mortality in Europe, Socio-Economic Determinants Based on Aggregate Data, Applied Economics Letters, 24(21): 1588-1596. DOI: $10.1080 / 13504851.2017 .1340565$.

108. THORNTON J., 2002, Estimating a Health Production Function for the US: Some New Evidence, $A p$ plied Economics, 34(1): 59-62.

109. UN population division, 2019, htpps://population.un.org/.

110. VON SCHIRNDING Y., MULHOLLAND C., 2002, Health and Sustainable Development: Key Health Trends. World Health Organization. Report of the World Summit on Sustainable Development, Johannesberg, Geneva 2002.

111. World Bank Database, 2020, www.worldbank.org.

112. World Health Organization, 2011, Closing the Gap: Policy into Practice on Social Determinants of Health, Geneva, Switzerland, http://www.who.int/ sdh conference/Discussion-paper-EN.pdf.

113. WHO 2008, World Health Report 2008: Primary Health Care Now More than Over, World Health Organization (WHO), Geneva, Switzerland.

114. WHO/UNICEF JMP, 2017, Progress on Drinking Water, Sanitation and Hygiene, WHO Library http://www.unwater.org/publications/whounicef-join t-monitoring-programwater-supply-sanitation-hygie ne-jmp-2017-updatesdg-baselines/.

115. World Health Statistics, 2020, Monitoring Health for SDGs, Sustainable Development Goals, World Health Organization, Geneva. 